\title{
Development of the Financial Sector and Its Impact on Economic Growth in the Western Balkans
}

\author{
Rovena Vangjel*, Jonada Mamo \\ Finance - Accounting Department, Business Faculty, Aleksandër Moisiu University of Durrës, Albania
}

Received December 5, 2021; Revised February 8, 2022; Accepted February 27, 2022

\begin{abstract}
Cite This Paper in the following Citation Styles
(a): [1] Rovena Vangjel, Jonada Mamo , "Development of the Financial Sector and Its Impact on Economic Growth in the Western Balkans," Universal Journal of Accounting and Finance, Vol. 10, No. 2, pp. 584 - 590, 2022. DOI: 10.13189/ujaf.2022.100223.
\end{abstract}

(b): Rovena Vangjel, Jonada Mamo (2022). Development of the Financial Sector and Its Impact on Economic Growth in the Western Balkans. Universal Journal of Accounting and Finance, 10(2), 584 - 590. DOI: 10.13189/ujaf.2022.100223.

Copyright@2022 by authors, all rights reserved. Authors agree that this article remains permanently open access under the terms of the Creative Commons Attribution License 4.0 International License

\begin{abstract}
The objective of this paper is to assess whether financial development may impact economic growth in the Western Balkans over the period 2005-2019. Development of financial sector is measured by credit to private sector, broad money, non-performing loans, and interest-rate spread. Economic growth is measured by the annual growth in GDP as a dependent variable. Empirically, panel data were used for six countries in the Western Balkans, specifically testing for random effects method (REM) and fixed effects method (FEM). First, we employed the descriptive and correlation matrices to determine whether the model is valid. To guide the selection of the REM or FEM, we ran a Hausman test, which resulted in an FEM across countries. The main conclusions of the paper are: (1) The economic growth is affected positively by the efficiency of banking sector; (2) The increase in depth and size of banking sector shows less relevance in economic growth. The insignificance of broad money and the negative effect of private credit, we can conclude that, for this period, these countries may have low levels of financial intermediation, or the amount of finance used by businesses and the financial sector is not productive for the economy.
\end{abstract}

Keywords Economic Growth, Financial Development, Panel Data Models, Financial Sector

JEL Classification: P2, G20, C23, O4

\section{Introduction}

The impact of the development of financial sector on economic growth in transition countries, such as Western Balkan countries, has not been discussed in previous empirical literature. The relationship between economic growth and development of financial sector has been debated in finance-economic literature for many decades. Most of the time, financial development has been recognized with the banking system due to underdeveloped financial markets of the transitions countries. The banking system is important because reduces information asymmetry between borrowers and lenders, reduces transaction and time costs, and provides financial resources for the economy. In a specific situation, the banking sector can evolve problematic behaviour displayed by adverse selection and then by moral hazard, which is reflected in inefficient allocation of resources leading to non-performing loans.

Many research studies have been conducted in this area and they conclude that financial development accelerates economic growth [1], [37], [9]. It has been claimed that development of financial sector can identify lucrative investment opportunities, reducing the cost of production, mobilize savings, promote technological innovations, and encourage investors to be more accepting of risk [1]. On the other hand, economists and other researchers have agreed on the contribution of the financial sector in economic growth, but others, such as Robinson [2], clearly stated in his study that, "where the enterprise guides, finance follows'. 
The empirical analyses that are conducted in this paper should provide if there is a link between economic growth and development of financial sector in Western Balkans. The importance of the topic is demonstrated on the fact whether larger, more efficient banking sector accelerate economic growth in these countries. Development of financial sector is measured by variables related to the banking system, as the size, depth, and efficiency of banking sector, because banks in transition economies are the important source of financial intermediation. Size and depth are measured by Broad Money to GDP and bank credit allocated to Private sector to GDP. The efficiency of banking sector is measured by interest-spread and non-performing loans. Section 2 summaries the literature references underlying this study, and Section 3 explains the methodology of the research. Section 4 presents the analysis model and its results, and Section 5 is devoted to discussions and conclusions.

The main conclusions of the paper are: (1) The efficiency of banking sector positively affects economic growth; (2) The increase in depth and size of banking sector shows less relevance in economic growth. The insignificance of broad money and the negative effect of private credit, we can conclude that, for this period, these countries may have low levels of financial intermediation, or the amount of finance used by financial actor is not productive for the economy.

\section{Literature Review on Development of Financial Sector and Economic Growth}

The role of financial institutions in accelerating economic growth has been discussed in most of the economic literature. Many decades ago, Schumpeter [3] identified the role of banking sector in financing technological innovations through their position as mediators. He [3] discussed that this goal could be achieved by the efficient allocation of savings through the identification and financing of entrepreneurs for their innovative ideas and production processes. Schumpeter stated [3], as did Levine [1], that economic growth was a product of interaction between financial and real innovations. The importance of financial markets and financial intermediaries in the economic development is emphasized by Schumpeter [3]. Hicks [4] held the same view, stating that finances played a crucial role in the industrialisation of developing countries. Financial development play an important role in innovation, in the rise of new firms, and thus diminish growth in indirect ways [37].

About the discussion of government intervention to financial system, government restrictions on the banking system (such as the setting of a ceiling for interest rates and direct interference in the lending process) shows negative effect on the development of the financial system, undermining economic growth [5].

Patrick [6] identified the so-called demand following, indicating that the demand for financial services depends on economic growth, trading, and the modernisation of sectors of the economy; and identified the so-called supply leading [6] indicating that the demand for economic growth depends on financial services. Patrick's two lines of thought have also been joined by other authors in which the link between economic growth and financial development is seen as two-way, where the factors can also be causing each other.

A study of 93 countries with a panel data model was conducted by Graff [7], for the period 1970-1990, emphasizing that financial development is an indicator of economic growth. In their paper, Jaffee and Levonian [8] assessed the state of banking system development in 23 transition economies of Central and Eastern Europe and the former USSR. Another empirical study of 25 transition economies conducted by Koivu [9], for the period 1993-2000, demonstrated a negative relationship between annual GDP growth and interest-rate margin. Cojocaru at al. [12] demonstrated that, in 25 countries in Central and Eastern Europe as well as the Commonwealth of Independent States for the period 1990-2008, there is a significant positive relationship between GDP growth and financial sector measured by credit to the private sector and a negative relationship between interest-rate spread and GDP growth. Interest-rate spread is another measure of financial sector efficiency related to interest-rate margin. Fink at al. [10], studying the relationship between financial development and economic growth in nine transitions economies, in 1996-2000, used the model of the production function. For a period of 1999-2006, were find a dependence between growth and the development of financial sector for 10 countries in Central and Eastern Europe [11]. Conversely, some studies found some evidence and arguments for an inverse relationship between economic growth and financial development [13], [14], [15], [16]. Indeed, the role of bank credit is considered important for economic growth and development [20]. Literature on financial economics supports the argument that countries with inefficient lending systems bear the risk of bankruptcy, while efficient lending systems grow more quickly [29].

\section{Methodology and Data}

Authors used to examine the link between the development of financial sector (through size/depth and efficiency of the banking sector) and economic growth (the dependent variable) in the Western Balkan states. This study includes a group of six Western Balkan countries categorized as upper-middle income economies by the World Bank [17]: Albania, Kosovo, North 
Macedonia, Bosnia and Herzegovina, Montenegro, and Serbia.

The relationship between financial development and economic growth is measured in the form of time series. The data used are quantitative and they are defined by the World Bank Group [28] and the development of financial sector is defined by the Structure Dataset by Beck at al. [18]. Secondary data collection is used at a macroeconomic level. King and Levine model [30] referred to research conducted previously by Goldsmith (1969) [31] used to measure financial development. One of their variables was the private credit, while GDP growth per person was one of their indicators of economic growth [37]. The model is based on variables below:

(1) Economic growth (as an annual percentage) as a dependent variable and

(2) Financial development measurements.

Several studies [30] have suggested that expected profits from financial depth are highly important. Financial development is intended to be measured through financial assets such as:

(1) Broad money growth (M2 growth annual percentage): This is a useful measure of the real scale of the financial sector in a growing economy, where money serves as a payment tool and a savings tool. Narrow money better reflects the function as a tool of payment, while broad money is a savings tool [23]. Broad Money measures the monetary value of transactions rather than the function of mobilising the savings made by the financial system. Therefore, it reveals that the system's ability is not how the funds are channeling from lenders to borrowers, but it is how financial services are provided. Consequently, non-developed economies can have a high value of money in the absence of alternatives to investment.

(2) Private credit to GDP (private credit as a percentage of $G D P$ ): This measure is often used to assess the allocation of credits because broad money cannot provide it. Thus, this variable is referring to investment equity and quantity, thus, to economic growth [32]. The level of lending to the private sector indicates financing innovative and sustainable projects.

(3) Interest-rate spread (lending rate minus deposit rate as a percentage). This indicator mentioned in Koivu [9] (as interest rate margin) and Cojocaru at al. [12], describes transaction costs within the sector through measuring the qualitative effectiveness of the banking sector. If interest rate spread increase due to the increase of transaction cost, investment will decrease because of the decrease of saving, diminishing economic growth (while we know that growth is linked to investment in positive way). Also, this variable reflects the borrower's quality in the economy.
(4) Non-performing loans (as a percentage of total loans): In transition countries, it is important to consider the weight of loans that have not performed well by inflating bank loans [33]. This variable indicates the relationships among banks, borrowers and depositors, the relationship between shareholders and supervisory institutions, the relationship within credit departments and how well a loan product has been designed for the clients. Non-performing loan is a variable that shows the quality of borrowing and the impact in the economy. A decrease of non-performing loans indicates an increase of economic growth because of an improved quality of investment.

For the testing of relationship between economic growth and financial development, the highly variable model is written in the form of a general vector model, a dependent variable, and other independent variables:

$$
i, t=\propto+\sum_{i, t=1}^{i, t=n} \beta_{i, t} F D_{i, t}+\sum_{i, t=1}^{i, t=n} \theta_{i, t} X_{i, t}+\delta_{i, t}+\gamma_{i, t}+\varepsilon_{i, t}
$$

Where:

$y_{i t}-$ GDP growth rate equals Economic Growth

$F D_{i, t}$ - broad money growth (annual percentage) and private credit (percentage of GDP)

$X_{i, t}-$ non-performing loans (percentage of total loans) and interest-rate spread

$\delta_{i, t}$ and $\gamma_{i, t}$ are the values of random model or fixed model;

$i-(1 \ldots N)$ indicates the country used in the model (Albania, Montenegro, North Macedonia, Kosovo, Bosnia Herzegovina, Serbia); and

$t-(1 \ldots T)$ indicates the year (2005-2019).

This study is to identify the connection between economic growth and financial development, below are some of the hypotheses to test this relationship.

\section{Hypotheses:}

(H1) Private credit has a positive relationship with GDP growth.

(H2) Broad money has a positive relationship with GDP growth.

(H3) Interest-rate spread has a negative relationship with GDP growth.

(H4) Non-performing loans have a negative relationship with GDP growth.

The assumption of the study is that the development of the financial sector is positively linked to the economic product [19]. In line with the literature, reports of intermediation and monetization of banking sector would measure financial size and depth. However, financial indicators are related to their ability to channel funds for borrowers from savers, even though there are other statements that imply that these financial indicators are closely related to the fact that financial development 
provides transaction services facilities [20].

We lack information on capital market development especially for countries such as Kosovo and Albania, so, this indicator is not used in this study.

\subsection{Method and Tests}

The authors used panel data from six countries in the Western Balkans. The data set of Beck et al. [18] provide most of the data and for the missing years (between 2005 and 2019) World Bank dataset were used. The EViews software was used for the empirical estimation. First, we run for correlation matrix and descriptive statistics between variables. Then we test for normality test. We analysed the data with standard procedures (pooled ordinary least squares) as well as Fixed Effect Model (FEM) and Random Effect Model (REM). REM means that differences in the level of financial development (measured by banking sector) are larger over time and smaller between countries. This is the case mostly in transition countries [9], such as Western Balkan countries. To accomplish FEM or REM, we use the Hausman test with the hypotheses below:

- Null hypotheses state that REM is significant

- Alternative hypotheses state that FEM is significant.
The test mentioned above will have a chi-squared distribution. If the test statistic is small, we should choose REM, while we chose FEM if the test statistic is large. Akaike information criterion test is used for the model's compatibility.

\section{Results}

Descriptive statistics are reported below in Table 1 and Table 2. We ran the Jarque - Bera normality test. This test resulted with a p-value of 0.1 greater than 0.05 , so, we accept the null hypothesis that the equation states that the function is normal.

From Table 1, the authors do not suggest a strong correlation between independent variables; however, the variables indicate mild correlation between private credit and interest-rate spread ( $p$-value 0.4645), interest-rate spread and broad money ( $p$-value 0.3198). If the correlation coefficient between two variables exceeds 0.70 , Wooldridge [24] would suggests presence of multicollinearity between variables. There is no multicollinearity between variables in the equation.

Some descriptive statistics are displayed in Table 2, such as, the mean, standard deviation, and maximum and minimum values for each variable.

Table 1. Correlation matrix

\begin{tabular}{|c|c|c|c|c|}
\hline & GDP Growth & Int Spread & Private Credit & Broad Money \\
\hline \multirow{2}{*}{ GDP Growth } & 1.000 & & & \\
& $\ldots \ldots$ & & & \\
& $\ldots \ldots$ & 1.000 & & \\
Int Spread & 0.197 & $\ldots \ldots$ & & \\
& 1.892 & $\ldots \ldots$ & 1.000 & \\
\hline \multirow{2}{*}{ Private Credit } & $(0.061)$ & -0.078 & $\ldots \ldots$ & \\
& -0.311 & -0.734 & $\ldots \ldots$ & \\
\hline \multirow{2}{*}{ Broad Money } & -3.070 & $(0.464)$ & -0.411 & \\
& $(0.002)$ & -0.106 & -4.228 & $\ldots \ldots$ \\
\end{tabular}

Source: Authors' calculations

Table 2. Descriptive statistics

\begin{tabular}{|c|c|c|c|c|c|}
\hline & Mean & Std.dev & Min & Max & Obs \\
\hline Broad Money & 36.009 & 30.38 & -10.11 & 119.15 & 90 \\
\hline GDP Growth & 3.296 & 2.522 & -5.79 & 8.76 & 90 \\
\hline Int Spread & 3.642 & 6.889 & -21.00 & 25.95 & 90 \\
\hline Private Credit & 44.124 & 13.36 & 15.37 & 86.52 & 90 \\
\hline
\end{tabular}

Source: Authors' calculations 
Table 3. Assumptions that specify possible relationships between banking sector and GDP growth

\begin{tabular}{|c|c|c|c|}
\hline Variable & Assumption 1 & Assumption 2 & Assumption 3 \\
\hline Broad money & $0.033\left(0.0274^{* *}\right)$ & $0.03\left(0.03^{* *}\right)$ & $-0.0016(0.28)$ \\
\hline Private credit_\%GDP & $-0.079\left(0.0069^{* *}\right)$ & $-0.08\left(0.003^{* *}\right)$ & $0.123(0.0535)$ \\
\hline Interest-rate spread & $0.03(0.57)$ & Dropped & $-0.23\left(0.0003^{* * *}\right)$ \\
\hline Non-performing loan & & - & $6.89\left(0.0001^{* * *}\right)$ \\
\hline Constant & $5.48\left(0.0007^{* * *}\right)$ & $5.48\left(0.0001^{* * *}\right)$ & 0.37 \\
\hline $\mathrm{R}^{2}$ & 0.21 & 0.20 & 0.296 \\
\hline $\mathrm{R}^{2}$ adjustat & 0.133 & 0.14 & $(0.24)$ \\
\hline $\begin{array}{c}\text { Hausman Test } \\
\text { Chi-squared }\end{array}$ & 8.28 & 7.9 & REM is appropriate \\
\hline $\begin{array}{c}\text { Hausman Test } \\
\text {-value }\end{array}$ & $\left(0.04^{* *}\right)$ & $\left(0.0186^{* *}\right)$ & $4.84(0.000)$ \\
\hline $\begin{array}{c}\text { Hausman Test } \\
\text { REM vs FEM }\end{array}$ & FEM is appropriate & FEM is appropriate & $74^{2}$ \\
\hline$F_{\text {-statistics }}$ & $2.7(0.01)$ & $3.08\left(0.006^{* *}\right)$ & 5 \\
\hline Number of observations & $90^{1}$ & 90 & 6 \\
\hline \begin{tabular}{c} 
Number of groups \\
\hline
\end{tabular}
\end{tabular}

Source: Authors' calculations

Significance at $(* * * p<0.001),(* * p<0.05),(* p<0.1)$

(1) years 2005-2019 (six countries)

(2) years 2005-2019 (five countries)

To study the relationships among variables for the six countries, three assumptions were conducted based on the approach by Dudian and Popa [26]. Table 3 presents some results from the analysis.

Due to data availability, we chose three assumptions for the study period 2005-2019:

Assumption 1 tests the relationship between broad money, credit to private sector (to GDP), interest-rate spread and economic growth, including all the six countries. We exclude the variable of Non-Performing Loan because this variable is not available for Kosovo.

According to the $p$-value, the part of credit to private sector (to GDP) and broad money is significant ( $p$-value < $5 \%$ ) and the share to interest-rate spread is not significant, so we eliminate it in assumption 2. GDP growth will decrease by 0.079 units if credit to private sector increases by one unit, which contradicts the hypothesis $\mathrm{H} 1$, meaning that credit to private sector and GDP growth are in negative relationship. $\mathrm{H} 2$ is approved and is true for the six countries surveyed, because there is a positive link between broad money and GDP growth, indicating that GDP growth will increase by 0.033 units if broad money increases by one unit. Also, in this assumption, interest-rate spread is positively related to GDP growth, revealing that GDP growth variable will increase by 0.03 units if interest-rate spread increases by one unit. However, this variable is not significant $(p=0.57)$.

Regarding selection of the REM or FEM, we ran a Hausman test, which resulted in fixed effects across countries, because the $p$-value $=0.04<0.05$, rejecting the null hypotheses that REM is appropriate (chi-squared statistic $8>3 d f$ ). This assumption indicates that $21 \%$ of GDP growth (dependent variable) is explained by the independent variables (coefficient of determination equals $21 \%)$. Also, the model is well-specified, indicated by $F$-test.

In Assumption 2, we dropped the interest rate variable since an increase in interest-rate spread can cause errors in the model. However, there are few differences in values, where the relationship of credit to private sector (to GDP) is still negatively connected with the GDP growth variable, again contradicting H1. Regarding selection of the REM or FEM, we ran a Hausman test, which results in fixed effects across countries (chi-squared statistic $7.96>2 d f$ ), $p$-value $=0.0186<0.05$, indicating that the FEM is more appropriate.

Assumption 3 tests the relationship between private credit to GDP, broad money, interest-rate and non-performing loans and economic growth for five countries, excluding Kosovo, because there is no data for non-performing loans. With the FEM, three variables are deemed not significant, and the only significant variable is non-performing loans ( $p$-value $\left.=0.000^{* *}\right)$ and the constant for $p<0.05$, while the interest-rate spread is significant only for $p$-value $<0.1^{*}$. This assumption between broad money, credit to private sector (to GDP), and interest-rate spread indicates that $37.37 \%$ of GDP growth (dependent variable) is explained by the independent variables (coefficient of determination equals 37.37\%). Also, the model is well-specified, as indicated by $F$-test. In this assumption, GDP growth will increase by 0.12 units, if interest-rate spread increases by one unit, indicating that 
there is a positive link between economic growth and interest-rate spread.

We ran the REM options, and with Hausman test $(p$-value $=0.24)$, we accept the hypotheses that the estimation has a random effect. The last assumption records the best values on the tests used, but most of the variables are not significant at $p=0.05$, so we assumed $p=$ 0.1 , while Kosovo has been excluded.

\section{Conclusions}

This study is an empirical effort, trying to identify the link between economic growth and the development of the financial sector for six nations in the Western Balkan region, using cross-sectional data for the period of 20052019 as secondary data collection. The methodology used was a panel data model of the FEM and the REM. The development of financial sector is measured by the indicator of financial depth and size as broad money growth and credit to private sector. Other variables as non-performing loans and interest-rate spread are used to measure banking efficiency. The analysis of data was in a panel data model, involving different periods of time and different countries.

As a summary of three assumptions, some conclusions are: (1) interest-rate spread is positively correlated with GDP growth even though it was not significant, (2) non-performing loans are negatively correlated with GDP growth, and it was significant, (3) an increase in the share of credits in private sector adversely negatively affects GDP growth and (4) the variable broad money is positively correlated with GDP growth, even though it was partially significant with it.

Same as our result, Haissam and Kichler [11] identified a strong negative relationship between non-performing loans and GDP growth. Different from our result, Koivu [9] with interest-rate margin and Cojocaru et al. [12] with interest-rate spread found a negative relationship with GDP growth. However, in our study, it was not significant at conventional level. This variable needs to be replaced with interest rate margin as Koivu [11] suggested for transition countries or a better sample will improve the result. In general, the results indicate that qualitative financial sector accelerates economic growth.

Contrary to other studies [12], this research highlights the fact that credit growth in the private sector negatively affects GDP growth. Additionally, Hagmayr et. al. [26], identified as significant and negative the effect of private credit for Southeastern Europe, explaining that quality of economic environment effects financial system. The Southeastern Europe includes countries from Western Balkans, implying why there are possible similarities in conclusions. The negative effect can be identified in countries where the financial system is low. Also, when independent variable is below $40 \%$, the ratio of credit to private sector to GDP results in a negative impact on economic growth [27]. The same was found in our sample (despite Bosnia Herzegovina and Montenegro). The negative link between private credit and growth may reflect bank restrictions on lending, that these countries as transitions economies [11] experienced during the research period. Thus, the amount of credit is not the best measure of financial development for these countries.

Due to unclear results of size and depth of banking sector we can conclude: (1) It is important to focus more on the financial structure to increase the flow of credit to the private sector and increase the financial depth of these countries. Financial systems that perform better, lead to improved financial services for a large part of the population [34], [35], [36]. Thus, with an increase in financial depth there would be improved capital distribution, a significant influence on the poor, less restriction on lending, promoted entrepreneurship, the formation of new firms and economic growth [37], (2) The amount of finance used by financial sector and business is not productive for the economy because they do not know how to improve capital distribution, how to promote entrepreneurship, and the fact that new firms are not innovative and efficient in respective economies, like Koivu [9] stated in his findings.

Nevertheless, it would be valuable to test the channels through which development of financial sector affects economic growth. As literature suggested, these channels might be trade openness, productivity improvement or foreign direct investment (FDI). Also, another useful extension of this study would be to include capital market in the model. Financial Markets in Western Balkan countries are far from developed and their role is limited, so it would be interesting to clarify their contributions in economic growth.

\section{REFERENCES}

[1] Levine R., "Financial Development and Economic Growth: Views and Agenda." Journal of Economic Literature, vol 35, no. 2, American Economic Association, pp. 688-726, 1997.

[2] Robinson J., "The Rate of Interest and Other Essays", Chapter "The generalization of the general theory", MacMillan, London, 1952.

[3] Schumpeter J. A., "Theorie der Wirtschaftlichen Entwicklung. Leipzig: Dunker \& Humblot, The Theory of Economic Development", 1912, translated by R. Opie. Cambridge, MA: Harvard University Press, 1934.

[4] Hicks J., "A Theory of Economic History", Oxford: Clarendon Press, 1969.

[5] McKinnon R., "Money and Capital in Economic Development", 1973.

[6] Patrick H., "Financial development and economic growth in underdeveloped countries", Economic Development Cultural Change", no 14, 174-189, 1966. 
[7] Graff M., "Financial Development and Economic Growth A New Empirical Analysis" Dresden Discussion Papers in Economics, No.5/99, 1999.

[8] Jaffee D., Levonian M., "The Structure of Banking Systems in Developed and Transition Economies, European Financial Management", 7, (2), 161-181, 2001.

[9] Koivu T., "Do efficient banking sectors accelerate economic growth in transition countries?" BOFITT Discussion Paper, No. 14/2002.

[10] Fink G., Haiss P., Vuksic G., "Importance of Financial Sectors for Growth in Accession Countries", Conference on European economic Integration 2005 (CEEI), ECB, OENB and CFS, Vienna, November 2005.

[11] Kichler E., Haiss P., "Leasing and Economic Growth Evidence for Central and Southeastern Europe", 36th Annual European Finance Association (EFA) Meeting, Norway, August 19-22, 2009.

[12] Cojocaru L., Hoffman S. D., Miller J. B., "Financial Development and Economic Growth in Transition Economies: Empirical Evidence from the CEE and CIS Countries", Working paper, No. 11-22, Department of Economics, University of Delaware, Newark, DE, 19716, USA, 2011.

[13] Singh A., "Financial Liberalisation, Stock markets and Economic Development, The Economic Journal", Volume 107, Issue 442, 1997.

[14] Andersen T. B., Tarp F., "Financial Liberalization, Financial Development, and Economic Growth In Ldcs," Journal of International Development, vol. 15, issue 2, 189-209, 2003.

[15] Ayadi R., Arbak E., Naceur S. B., De Groen W. P., "Financial Development, Bank Efficiency and Economic Growth across the Mediterranean", MEDPRO Technical Report No. 30/March 2013.

[16] Ductor L., Grechyna D., "Financial Development, Real Sector, And Economic Growth" International Review of Economics \& Finance, vol. 37, issue C, 393-405, 2015.

[17] OECD, ETF, EU, EBRD, "SME Policy Index: Western Balkans and Turkey 2019: Assessing the Implementation of the Small Business Act for Europe, SME Policy Index", OECD Publishing, Paris, 2019, DOI: org/10.1787/g2g9fa9a-en

[18] Beck Th., Demirgüç-Kunt A., Levine R., "A New Database on Financial Development and Structure updated September 2015", World Bank Economic Review 14, 597-605.

[19] King R. G., Levine R., "Finance and Growth: Schumpeter Might be Right, The Quarterly Journal of Economics", Vol. 108, No. 3, pp. 717-737, 1993.

[20] Khan M., Senhadji A., "Threshold effects in Relationship
Between Inflation and Growth”, IMF working paper/00/110, 2000.

[21] Beck T., Levine R., Loayza N., "Finance and the Sources of Growth", Journal of Financial Economics, 58 (1-2), 261-300, 2000.

[22] Levine R., "Bank-based or market-based financial systems: Which is better?", Working Paper 0005, 2000.

[23] Dushku E., "Zhvillimi Financiar dhe Rritja Ekonomike: Rasti i Shqipërisë", Buletini Ekonomik, Banka e Shqipërisë, 12, 143, 2009.

[24] Wooldridge J. M., "Econometric analysis of cross section and panel data", MIT press, 2010.

[25] Dudian M., Popa R. A., "Financial development and economic growth in Central and Eastern Europe", Theoretical and Applied Economics, Volume XX, No. 8(585), pp. 59-68, 2013.

[26] Hagmayr B., Haiss P. R., Sümegi K., "Financial Sector Development and Economic Growth - Evidence for South-Eastern Europe”, Europa Institute, 2007.

[27] D'Alfonso E., Moretti L., "The Finance-Growth Nexus in CEE: New Evidence from a Survey-Based Indicator of External Finance Dependence", Economics Bulletin, Vol. 32, No. 3, pp. $2688-2699,2012$.

[28] World Bank Group, "Western Balkans Regular Economic Report", Greening the recovery, No.200, Fall 2021

[29] Kasekende L., "Developing a Sound Banking System". Tunisia: Paper presented at IMF Seminar, 2008.

[30] King R., Levine R., "Finance, entrepreneurship, and growth: Theory and evidence", Journal of Monetary Economics, 32, pp. 513-542, 1993.

[31] Goldsmith R. W., "Financial Structure and Development", New Haven, Yale University Press, 1969.

[32] Gregorio J. D., Guidotti P. E., "Financial Development and Economic Growth", pp. 433-448, 1995.

[33] Fink G., Haiss P., Mantler H. C., "The finance-growth nexus. Market economies vs. transition countries", Europainstitut, 64, 2005.

[34] Haber S., Maurer N., Razo A., "The Politics of Property Rights: Political Instability, Credible Commitments, and Economic Growth in Mexico", 2003.

[35] Rajan R., Zingales L., "Saving Capitalism from the Capitalists. Random House”, 2003.

[36] Morck R., Wolfenzon D., Yeung B., "Corporate governance, economic entrenchment and growth". Journal of Economic Literature, In press, 2005.

[37] Rajan R., G., Zingales L., "Financial Dependence and Growth" The American Economic Review, vol. 88, no. 3, American Economic Association, pp. 559-86, 1998. 